\title{
Promises, promises: self-regulation of US cigarette broadcast advertising in the 1960s
}

\author{
Richard W Pollay
}

\begin{abstract}
US broadcasters, advertising professionals and politicians joined health advocates in the 1960s in calling for controls of cigarette promotional practices, particularly on radio and television. The tobacco industry repeatedly responded with seemingly sincere promises and instituted self-regulation codes and procedures, first using the Tobacco Institute and later the National Association of Broadcasters. The disclosures of advertising industry insiders, the evaluations of the advertising trade press and new analyses of media sponsorship buying patterns all indicate that these efforts were more cosmetic than effective managerial controls. When anti-smoking messages were mandated onto US broadcast media, the cigarette industry volunteered to abandon broadcast advertising. The ultimate legislation to stop broadcast ads, had the effect of eliminating the requirement that air time be provided free for pro-health public service announcements. Sponsorship of sport events and teams began almost instantly, creating television promotional exposure, now with no health warnings. This well-documented American experience suggests that other countries should not rely exclusively on industry self-regulation, as its promise is likely to far exceed its performance.
\end{abstract}

Tobacco Control 1994; 3 : 134-144

\section{Introduction}

The cigarette and advertising industries have long promoted self-regulation as the preferred means of effecting meaningful reforms to marketing and promotional activities. Health officials and legislators in many countries are often tempted to accept what seem to be promising proposals for self-regulation, and to abandon the political struggle to obtain meaningful legislative controls. In the absence of Congressional or regulatory initiatives on the cartoon Camel campaign, the US Surgeon General recently resorted to moral persuasion in a plea for self-regulation by RJ Reynolds, its advertising agencies, and the magazines, newspapers and retailers carrying the product and its ads. ${ }^{1}$ This hope for and reliance upon cigarette industry good will and ethical behaviour seems to be often misplaced, as cigarette self-regulatory guidelines and pro- cedures are notorious for having several critical weaknesses: excluding the most grievous of practices, excluding sports sponsorships and other indirect promotion, providing no clear authority or meaningful sanctions, using weasel words in guidelines, ignoring the amount and pervasiveness of cigarette advertising, failing to have a decision-making body at arms length from the industry, functioning to protect cigarette competitors from one another's advertising more than protecting consumers, being reluctant and belated in rendering any judgements, and being ignored by the industry. ${ }^{2}$ Nonetheless, because selfregulatory codes are employed by the cigarette industry to deflect other proposals, such as those for advertising curtailments or bans, there has been a recent call for research into both the design and implementation of such codes. $^{3}$

Other research on the US cigarette industry's recent initiatives has found them wanting. One survey of retailers found that less than $5 \%$ were participating in the "It's the Law" programme and that they showed no improved compliance with the state law forbidding sales to minors. ${ }^{4}$ In stark contrast, dramatic success has been achieved with a municipal law enforced by compliance checking. ${ }^{5}$ The Tobacco Institute's "Helping Youth Decide" and "Helping Youth Say No" booklets have been criticised for omitting any discussion of addiction, advertising, or the importance of parental example, and also for being based on theoretical approaches known to be ineffective. ${ }^{6,7} \mathrm{~A}$ study of British practices found breaches of the voluntary agreement between the tobacco industry and the government to be common, with monitoring virtually non-existent. ${ }^{8}$

In the meantime, cigarette firms continue to research and attract youths with Marlboro men and other mythical images of independence or rebellion, such as the cartoon characters with attitudes who symbolise Camels and Kools. ${ }^{9,10}$ Cigarette firms, of course, "vehemently, unequivocally and unilaterally deny any youth-directed marketing efforts", but both historical and contemporary evidence displays their strategic interest in the young. ${ }^{9-12}$ The Tobacco Institute asserts that the 1964 selfregulatory code eschewing all promotion to young people is still observed, and that they left radio and television in 1969 "because of their substantial and expanding audience of young people". ${ }^{13}$

Cigarette marketing and advertising's effect
Archives,

Faculty of Commerce, Columbia

Vancouver, Canada V6T 1Z2 
on youth was an even more prominent social and political issue in the 1960 s than now. Cancer news was more novel and television ads glamorising smoking exposed children in their parent's living rooms. Broadcasters and advertising professionals, not just health advocates, asked the cigarette industry to avoid copy appeals and media buying that exposed and tempted children and teens. The announced self-regulatory measures made it seem that they had capitulated to this moral persuasion, but subsequent events would put this in doubt.

PURPOSE

The purpose of this paper is to understand better this chapter in the history of the cigarette advertising, in order to understand the potential and limitations of advertising selfregulation by the cigarette industry. After a preamble on advertising self-regulation in general, the cigarette industry controversy and conduct in the 1960s is described, focusing on advertising and the young. Three self-regulatory episodes are covered: $(a)$ the Tobacco Institute's "suggestions" of 1963; $(b)$ the National Association of Broadcasters' (NAB) code of 1965; and (c) the Federal Communications Commission's (FCC's) application of the Fairness Doctrine and the subsequent 1969 cigarette manufacturers volunteering to abandon radio and television. The effectiveness of cigarette advertising self-regulation is examined by considering the audiences delivered by the television buying patterns, descriptions of insiders' evaluations of the NAB code effectiveness, a review of the legislative history of the broadcast advertising ban, and observations from the advertising trade. In brief, this review discusses the problem of cigarette advertising and the young, the cigarette industry's repeated promises and its actual performance.

This historical review has several potential benefits. Perhaps the most important are the lessons it can provide to policy makers in other countries facing similar issues and self-regulation promises. Broadcast advertising is still permitted in many jurisdictions and the advertising seen is often reminiscent of that shown on US television in the 1960s and in violation of the regulatory codes for domestic US advertising (eg, celebrity endorsements).$^{14}$ Even where explicit cigarette ads are not permitted on the television, indirect forms of promotion often appear through the news coverage and advertising of event sponsorships and "brand-stretching" activities (eg, travel agencies, clothing, music stores, and contests). Certainly the issues in other countries are virtually the same as in the US then and now (eg, concerns over unwarranted health reassurances, both explicit and implicit, and the promotional association of cigarettes with athletics, romance, celebrities, and other youthful interests). This review can, of course, also inform current policy deliberations in the US and is highly relevant to liability litigation where advertising practices of the 1960 s are considered.
ON ADVERTISING SELF-REGULATION

The literature about or on behalf of advertising self-regulation is substantial. ${ }^{15-18}$ Even among its advocates, self-regulation is seen as only a supplement to market, community, and state controls. Its "true role is to spread and improve advertising standards" rather than to be a consumer redress mechanism or "the systematic invitation, collection and handling of complaints". Advertising self-regulation, when effective, reinforces norms from the community, market, and state and leads to the internalisation of standards, generating " moral adhesion" to them. "Advertising self-regulation is more moral and ethical than disciplinary." Because typically a relatively informal process among peers, it has the potential for more pragmatic and realistic decisions and lower administrative costs than formal litigation. Self-regulation systems are tolerated industry collusions designed to control issues important to the industry: evasion by "free riders" and "bad image, unbridled competition and overregulation". ${ }^{19}$

For self-regulation to fulfil its promise, however, the processes must be properly institutionalised, funded, supervised, promoted and accessible to the public or its representatives, not just industry insiders. The codes must be relevant, operational, and involve minimal ambiguity and subjectivity, as experience shows that self-regulatory units are reluctant or unable to deal effectively with subjective issues like good taste, decency or sexism. Reliance on self-regulation has long been judged a dubious public policy when the risks and consequences of its failure are large (eg, life and death issues) or when corporate collusion seems likely. ${ }^{20}$ Boddewyn, an advocate of both self-regulation and the cigarette industry, admits: "Self-regulation is neither a panacea nor a complete substitute for other forms of social control. Its scope is limited, its reach is incomplete, and its methods are only partially effective," and it is highly unlikely to "enact bans against controversial products". Advertising self-regulation works best as a quality control of advertising or as a check on the inappropriate behaviour of employees "rather than of management's intention to mislead ... The really bad apples are best left to government agencies". ${ }^{19}$

The primary criticisms of advertising selfregulation in general are like those experienced for tobacco: it handles too few cases, is given too little publicity, has too little authority and sanction power, provides belated decisions, imposes penalties that are too mild, and decides the many borderline cases in favour of industry interests. Despite this pervasive general problem, many people are encouraged by the cigarette industry to place substantial faith in self-regulation as being efficacious and preferable to legislation and regulation by governments. The advertising and media industries, not surprisingly, join in vigorously promoting self-regulation, especially when legislation is contemplated. ${ }^{15}$ 
The primary problem : cigarette advertising and children

The US cigarette industry has long found advertising an effective selling tool, realising industry growth and protecting the industry size. The nature of the advertising in the 1950 s, with its heavy use of endorsements by athletes and doctors, and explicit verbal health claims, slogans and reassurances, led to vigorous debate in the advertising trade press about the need for self-regulation. ${ }^{21}$ One Better Business Bureau attacked cigarette ads as violating broadcast industry guidelines, the Radio Creed and the Television Code, because of the use of paid testimonials, "independent research laboratories", and misleading terminology. ${ }^{22}$ The American Medical Association (AMA) attacked the "cigarette hucksterism" and outrageous commercial exploitation of the medical profession for the campaign that implied that the Kent Micronite filter (which then contained asbestos, see Tobacco Control 1994; 3 : 64) solved the health problems of cigarettes and was endorsed by the AMA. ${ }^{23}$

The cigarette industry attempted a ceasefire in the escalating tar war, the head-to-head advertising competition over tar delivery and health claims. Like a price war, this competition was inimical to the industry's interest, in this case because it inflamed public concerns about the health question. The Federal Trade Commission (FTC), through its Bureau of Consultation, was co-opted into being the cease-fire administrator. ${ }^{24}$ By 1960 , both broadcasters and the advertising trade press felt the need for greater regulation of television advertising of all products, not just cigarettes, because examples of "blatancy, poor taste, misrepresentation, coarseness and deception" were numerous, and not just a "noxious, crawly few".$^{25}$

By 1963 the cigarette firms were relying heavily on television, spending the majority of their total promotional budget on this one medium. ${ }^{26,27}$ Their faith in the efficacy of advertising led to record promotional spending and corresponding increases in sales and profits. ${ }^{28-31}$ According to Fortune magazine, cigarette firms looked forward to continuing increases in sales, specifically "among the teenagers... (who) have not been much impressed by any anti-smoking campaigns" that were stimulated by the 'health scare' of the $1950 \mathrm{~s}^{32}$ Cigarette firms were heavily involved in advertising, sampling distribution, and promotions on college campuses. ${ }^{33}$ They were also reaching a "captive audience" of "children of all ages" through programme ads and clown gags in the Ringling Brothers and Barnum \& Bailey Circus. ${ }^{34}$ Gilbert Research, a marketing research firm specialising in the young, reported that smoking rates among those aged 13-19 years were up to $35 \%$, compared to $25 \%$ two years earlier, with $44 \%$ of graduating seniors smoking. This represented an impressive $40 \%$ increase in the teenage smoking rate over these two years. Even if a crude estimate, the growth was surely substantial and an impressive testimony to the power of television advertising. When reporting this study, Fortune commented: "Cigarette ads often portray and seem to be pitched directly at young people". ${ }^{35}$

There were, of course, criticisms of these successful selling efforts. Some non-commercial sources, such as the Consumers Union and Reader's Digest, openly questioned the propriety of cigarette industry behaviour. ${ }^{36,37}$ Reader's Digest named American Tobacco, RJ Reynolds, and Lorillard as aiming at the young, noting the hiring of student campus representatives to distribute samples and the dominant presence of cigarette advertising in campus publications. "Nowhere in that bright wonderful world depicted in cigaret (sic) ads is there any hint to youngsters that cigarets (sic) might be harmful.,"38 The National Congress of Parents and Teachers invoked an analogy to Communist brainwashing and described the glamorous but uninformative advertising as "smoke-washing". 39 Much of this criticism and concern was, however, muted in the public forum by the age-old reluctance of commercial media to offend their highly lucrative sponsors. ${ }^{40}$ By late 1963 the first Surgeon General's report was anticipated with much discussion of the probable legislative responses it might precipitate. ${ }^{41,42}$ Of particular concern was the cigarette industry's sponsorship of sports, use of athletes' endorsements, and other ad tactics appealing to the young.

Sports sponsorships were commonplace and involved all the firms. Liggett \& Myers had long been associated with baseball, regularly sponsoring games and using athletes' testimonials in ads. In 1963 RJ Reynolds sponsored eight different baseball teams and American Tobacco sponsored six more. ${ }^{43}$ Reynolds was also contracted to the National Collegiate Athletic Association and Brown \& Williamson sponsored college football Bowl games. ${ }^{44,45}$ Lorillard had signed to sponsor the Olympic Games of 1964 and was already broadcasting previews. ${ }^{46}$ Philip Morris' Marlboro, which used athletes' endorsements to appeal to African-Americans, sponsored National Football League games on CBS and the championship games on NBC. ${ }^{47-49}$ American Tobacco used New York Giants football star Frank Gifford to promote Lucky Strikes as "the brand to start with". 50

Both the leading advertising trade magazine and a leading advertising industry executive, John Orr Young of Young \& Rubicam, saw effective marketing to the young as important to the cigarette industry to at least maintain the industry's size and perhaps foster further growth. ${ }^{51}$ Advertising trade magazines felt that "until now, most (cigarette) advertising has been directed to a young market in an attempt to create new consumers." ${ }^{22}$ Headlines bluntly stated that "cigarette ads aim at youngsters still". ${ }^{33}$ Some judged the use of athletes problematic because it implied a healthfulness that was unwarranted and because it was a means of appealing to teenagers. Advertising Age wrote an editorial counselling the cigarette industry to put less emphasis on youth and athletes in their ads. ${ }^{54}$ 


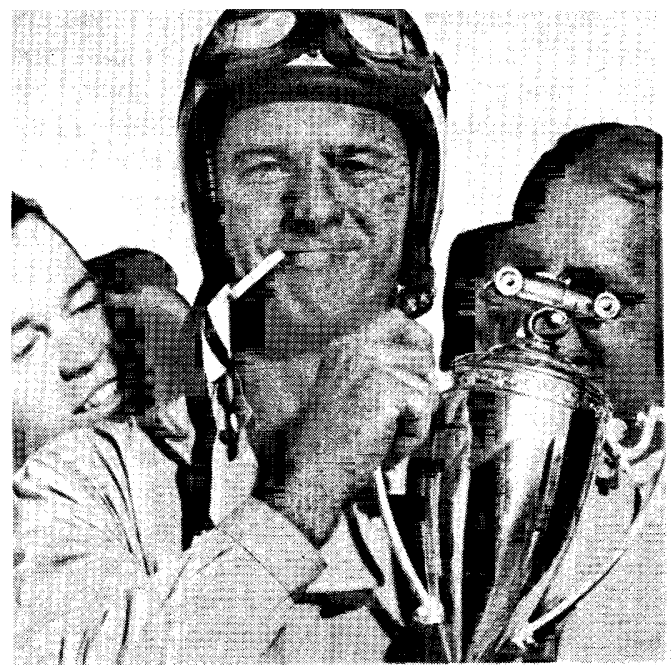

Lucky Strike separates the men from the boys....

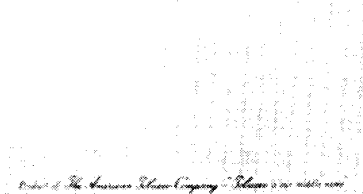

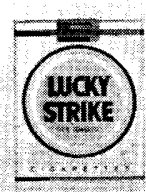

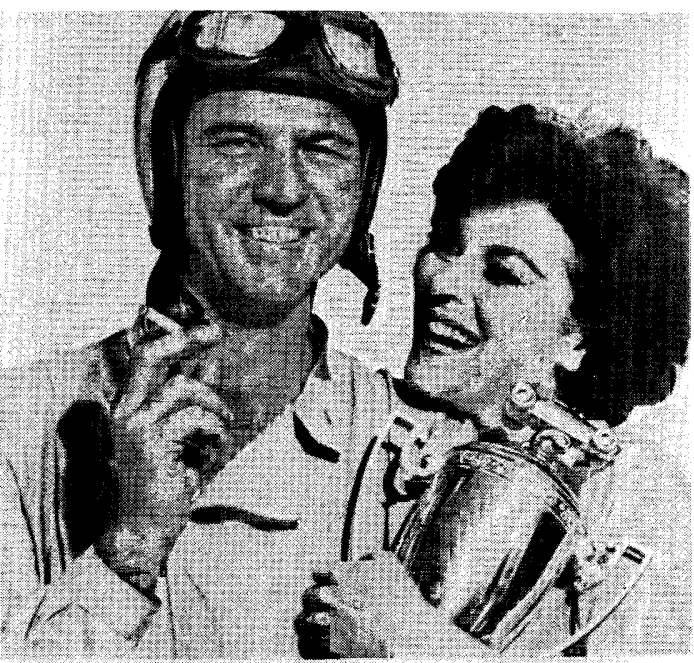

but not from the girls.

Smoking is a pleasure meant for adults. And

Lucky Strik's fine tobaccos are blended

for adult tastes. If you're an adult smoker, remember LS.M.F.T.-Lucky Strike means fine tobacco. tet all the taste you could ask for. Ask for Lucky Strike.

The most provocative and surprising of the insiders' comments may have been the NAB presidential address by Leroy Collins in 1962. After noting that more and more children of high school age were becoming habitual cigarette smokers, he explicitly blamed cigarette advertising. "We also know that this condition is being made continually worse under the promotional impact of advertising designed primarily to influence young people," arguing that the broadcast industry should institute self-regulatory codes because "moral responsibility demands it". ${ }^{55}$ With $\$ 134$ million of broadcast ad spending at stake, the networks instantly disassociated themselves from the suggestion. ${ }^{56}$ By the next year, however, the NAB followed Collins' leadership and stated that "tobacco advertising having an especial appeal to minors, expressed or implied, should be avoided. ${ }^{, 57}$

The campaign that drew the most specific criticism for its copy was American Tobacco's effort for Lucky Strikes. In the summer of 1963, "the brand to start with" was replaced by a new slogan: "Luckies separate the men from the boys, but not from the girls" ${ }^{58.59} \mathrm{~A}$ typical rendition showed a boy looking longingly at the rewards of maturity, for example, a racing car driver simultaneously enjoying a cigarette, a victory trophy and the admiration of a beautiful woman (see figure). The president of the NAB called the campaign a "brazen, cynical flouting of the concern of millions of American parents about their children starting the smoking habit... They well know that every boy wants to be regarded as a man." Advertising Age columnists and editorials joined in condemning the campaign as "a too-clever, too-cynical attempt ... This is advertising we can do without" ${ }^{61,62}$ Printers' Ink gave an end-of-year plaudit to Leroy Collins for "raising the question of ethics" and simultaneously condemned the Tobacco
Institute for its "devious defense of smoking" and American Tobacco for "callously continuing" the campaign. ${ }^{63}$

\section{Act 1: Tobacco Institute "suggestions" THE PROMISES}

In the face of this criticism, the six major firms in the cigarette industry claimed to drop virtually all advertising in college football programmes, radio stations, magazines and newspapers. ${ }^{64}$ While nominally conciliatory, it left alone the far larger budget for television advertising and other teen-targeting practices, such as the nearly $\$ 2500000$ spent by Reynolds on teen radio stations in after-school hours, a practice they didn't even claim to limit until the following year. ${ }^{65}$

Cigarette industry executives met in the summer of 1963 to discuss restrictions on the character of its television advertising, using the Tobacco Institute as a framework to avoid collusion charges. ${ }^{66}$ The Tobacco Institute's "suggestions" included one that programmes "whose content is directed particularly at youthful audiences should not be sponsored or used. Thus, good judgement in program content, rather than arbitrary restriction of sponsorship to certain hours of the listening or viewing day, should be the determining factor". The Tobacco Institute took pains to note that it itself did not monitor or regulate the advertising of its members, but the chief executives of all of the major firms except Brown \& Williamson instantly endorsed the suggestions, indicating that they would display the necessary judgement and self-regulatory restraint. Lorillard "would review current commercials to see that they are in keeping with the Institute's suggestions." Reynolds was in "hearty agreement" and Liggett \& Myers thought the suggestions "good" and deserving of "thoughtful attention". 
American Tobacco said its own polices were already "completely in accord" and Philip Morris, too, said that its advertising "has for some time conformed to the principles suggested". ${ }^{67}$

THE PERFORMANCE

These events drew the scorn of Senator Maurine Neuberger, a leading congressional critic of tobacco marketing practices, who felt that the self-regulatory suggestions were an "exercise in futility" and "motivated by a desire to head off government regulation." $" 67$ To what extent did the cigarette industry follow this Tobacco Institute suggestion to avoid sponsoring programmes that attracted audiences heavy with children?

A re-analysis of a complete inventory of the television programmes sponsored by cigarette firms in the autumn of 1963 indicates that they did not avoid these programmes and may have systematically selected them (see companion paper published on pp 130-3 of this issue of Tobacco Control). The six US cigarette firms sponsored 55 shows and a total of 62.5 hours of television every week, most of it at prime times. The young were roughly $25 \%$ or more of the audiences for every firm except Brown \& Williamson. That this was the one firm that bought a more adult audience is ironic, as it was also the only firm that did not instantly and publicly endorse the Tobacco Institute principles. The average teenager saw over 100 cigarette ads per month on television, and the amount of cigarette sponsorship across various prime-time slots was significantly correlated with the proportions of teenagers watching. This seems to have been another manifestation of the cigarette industry's strategic interest in youth. It certainly demonstrates the inadequacy of the Tobacco Institute's efforts to activate effective self-regulation. US youth in 1963 remained heavily exposed to the inducements of television advertising. ${ }^{68}$

This might seem to be only because of a slow administrative start, or because of unbreakable commitments to particular networks, but instead of improving with time, this problem seems to have got worse. The FTC analysed the cigarette advertising schedules and audiences of January 1967 and found that the 60 cigarette-sponsored shows were reaching children more effectively than they were adults. Adults, on average, saw the ads on 5.9 programmes a week while 13- to 17-year-olds saw the ads on 7.8 programmes a week, suggesting to the FTC that "teenagers appear to be a prime target for televised cigarette advertising".69

\section{Act II - Advertising agency ethics and broadcaster efforts}

The release of the first Surgeon General's report on smoking and health in 1964 made the issue of cigarette promotion prominent again, with varying reactions from the advertising profession, the media community, and policy makers in Washington, DC. The professional communities had the opportunity to respond through the exercise of either $(a)$ professional ethics and moral restraint within the advertising industry and/or (b) broadcast industry organised self-regulation processes.

\section{ACTIONS BY ADVERTISING AGENTS}

Just before the release of the first Surgeon General's report in 1964, Advertising Age stated emphatically: "It seems safe to say that no advertiser, no agency man and no media would want to continue advertising cigarets (sic) if it were clear that they pose a serious and positive danger to the health of the ordinary smoker...let's not have any more sidestepping". ${ }^{70}$ When the unequivocal report appeared, several major advertising industry leaders acted accordingly. They clearly acknowledged advertising's role in building and sustaining demand, and publicly avowed that their namesake ad agencies would quit or refuse cigarette advertising accounts on moral grounds: Bill Bernbach ${ }^{71}$ of Doyle, Dane, Bernbach; David Ogilvy ${ }^{72}$ of Ogilvy and Mather; Nelson Foote ${ }^{73}$ of Foote, Cone and Belding; and John Orr Young ${ }^{74}$ of Young \& Rubicam.

Young commented candidly: "Advertising agencies are retained by cigaret (sic) manufacturers to create demand for cigarets (sic) among both adults and eager youngsters. The earlier the teen age boy or girl gets the habit, the bigger the national sales volume." "74 The president of McManus, Johns \& Adams proposed that anti-smoking forces could make cigarettes "unfashionable" by running advertising "prepared with all the skill and motivational psychology and creativity that a top-rank advertising agency can muster... There is no doubt that all forms of advertising played a part in popularizing the cigaret (sic)" ${ }^{75}$ Even a Marlboro ad man later admitted to second thoughts about cigarette advertising: "I don't think cigarettes ought to be advertised ... I don't know any way of doing this that doesn't tempt young people to smoke." 76 (p245)

The majority of the advertising community did not follow this moral leadership, however. A survey by Advertising Age found that most were still willing to handle cigarette accounts and "agencies with cigaret (sic) clients in the shop vigorously supported the industry."77 A small Printers' Ink survey found that not one in 20 cigarette copywriters admitted to any pangs of conscience. ${ }^{78}$ Mary Wells Lawrence, whose agency had thrived on the Benson \& Hedges account, said: "When the government shows me beyond doubt that no matter who you are and what your make up is cigarettes can cause you to contract these diseases, I'll search my soul about the moral problem."79(p45) She required certainty, universality, and explicit causation. Then, and only then, would she engage in moral reflection. 
MORE PROMISES - ACT II

The second round of self-regulatory promises was provoked and administered by the broadcast media, through the mechanism of the NAB. They asked that programmes delivering youthful audiences and copy appeals to young people both be avoided: "care should be exercised so that cigaret (sic) smoking will not be depicted in a manner to impress the youth of our country as a desirable habit worthy of imitation. "80 A tobacco industry committee of lawyers drafted the code of self-regulation to require that models be at least 25 years old, and to stop appeals to children, implications of healthfulness, implications that cigarettes were essential to success, the use of college media, comic books or testimonials from athletes, and advertising on programmes whose audiences were primarily youth, with potential fines up to $\$ 100000 .^{81-83}$ The developed code and its administrative processes were favourably reviewed by the US Department of Justice, indicating that this cigarette industry collusion would not be seen as a violation of anti-trust law. ${ }^{84}$ When arguing that other FTC action and congressional legislation were unnecessary, the Reynolds' president described this broadcast code as "a sincere attempt by the industry to respond to criticism ... an earnest effort at industry self-regulation". ${ }^{82(p 285)}$ The president of Philip Morris echoed this sentiment, calling it "strong, strictly administrated, carefully conceived and seriously carried out". 85

\section{PERFORMANCE - ACT II}

The code got off to a weak start and soon appeared to have "lost impetus" and become a "phantom code" with only some firms submitting ads, none being rejected, and only one or two conferences called. ${ }^{86}$ When finally more organised, strict interpretations and adherence "for the first six months" were expected, but "after that expect to see a subtle loosening in interpretation of the restrictions." 87 The advertising trade press also predicted that there would be periodic disclosures of code applications to create public perceptions "that the manufacturers are serious in their attempt at self-regulation," but noted that the NAB had no direct authority and that there were significant gaps in the code, especially the issue of ad placement and the audiences reached thereby. ${ }^{88}$

The principal code administrator, former Governor of New Jersey, Robert Meyner, was stunned at the size of the job and the amount and variety of cigarette advertising and promotional materials. He was awed by the inventory of "television, radio and cinema commercials of all types, newspaper and magazine advertisements, billboards, posters, signs, and the so-called car cards you see in busses and subways and railroad cars. It includes the decals on automobiles and trucks and the signs and posters on autos and buses. It includes calendars, pamphlets, handbills, matchbook advertising, and the various and very numerous point-of-sale display materials. Ad- vertising under the code means the package of cigarettes itself. It means the carton and the shipping case. It means the decorative sleeves that dress up the carton during the Christmas season. It also means the giveaways like ballpoint pens and lighters - the cards to play the game and the paper to tally the score. Advertising also embraces a variety of promotional letters, brochures and other literature ... a mountain of material... It has been an instructive experience; I never realized before the sweep and penetration of advertising generally in our way of life."

The code's rules were revised several times over the next few years, sometimes to provide operational clarifications, sometimes to relax the rules, such as those governing the use in ads of heavy exercise sports equipment, and at least once to pre-empt a total broadcast ban. ${ }^{89-92}$ By 1967, both Lorillard and American Tobacco had withdrawn from the code, apparently over the launch advertising of True and Carlton, respectively. ${ }^{93,94}$

Unfortunately, the implementation of the code, like the self-regulation of 1963 documented above, left much to be desired, with few changes that consumers might notice. While the code provided for fines up to $\$ 100$ 000 , no record exists of their imposition. Some changes were small and had mysterious motivation, such as disallowing the use of "recessed filter" but permitting "filter that is recessed." 95 Advertisers did not seem to find its administration particularly restrictive. "Four months after the code was formulated, Viceroy ads featured young tennis players lighting up after a hot game. Salem showed a young couple playing giggling games alongside a waterfall...A television commercial producer admitted it didn't matter how young the models looked, or how youthful were their actions, so long as they possessed 'over twentyfive' birth certificates. In fact, his quest now is for older models who 'looked young'."96(p116) Others may have shared this motivation, for corporate documents now available disclose cigarette advertising goals in 1964 of increasing the number of people "who think of the brand as being for someone starting to smoke" and "to increase the proportion of beginning smokers". ${ }^{97(\mathrm{pp} 14,16)}$

Particularly ineffective was the rule regarding audiences "primarily" young. The operationalisation disallowed cigarette advertising on television programmes whose audience was $45 \%$ or more under 21 years of age. ${ }^{98}$ In addition to the striking laxness of this criterion, its application also allowed the continuation of the sponsorship of "The Beverly Hillbillies" by Reynolds, despite the fact that two successive episodes had $50 \%$ and $45 \%$ of its audience under 21 . An interpretation held that the prohibition would be applied only on the basis of two successive monthly audience analyses, not for specific episodes. ${ }^{99}$ Advertising wasn't stopped until later monthly data showed similar high levels of minors. ${ }^{100}$

The head of the key New York office of the Code Authority, Warren Braren, testified to a 
Congressional hearing that the NAB clearance process was little more than public relations window dressing as "the Code Authority ceased trying to formulate its own policy on cigarette advertising, and broadcast self-regulation became synonymous with trade association lobbying." $101,102 \mathrm{He}$ described it as a "failure in controlling cigarette commercials which appeal to young people" and as a preemptive strategic move "to avoid meaningful self-regulatory action as long as the possibility exists that Congress will enact legislation favorable to the broadcasting and tobacco industry."103(pp93-4)

Other NAB personnel attempted to temper and qualify Braren's charge, but a leaked internal NAB document noted that the volume and character of cigarette advertising was still very likely to be impactful on the young and was, therefore, still problematic. ${ }^{104}$ "Despite changes which have been brought about in cigarette advertising on radio and television, the cumulative impression created by virtually all of the individual campaigns supports a finding that smoking is made to appear universally acceptable, attractive and desirable... The difficulty in cigarette advertising is that commercials which have an impact upon an adult cannot be assumed to leave unaffected a young viewer, smoker or otherwise. The adult world depicted in cigarette advertising very often is a world to which the adolescent aspires. The cowboy and the steelworker are symbols of a mature masculinity toward which he strives. Popularity, romantic attachment and success are also particularly desirable achievements for the young. To the young, smoking indeed may seem to be an important step towards, and a help in growth from adolescence to, maturity." $105,106(\mathrm{pp} 30-1)$ By its own admission, and like the Tobacco Institute before it, the NAB had failured to protect the young from the inducements of cigarette advertising.

\section{Act 3: Regulatory initiatives and responses}

The FTC had earlier noted that both the media placement and the messages seemed destined to attract the young, regardless of intent. "Whether through design or otherwise, cigarette advertising is so placed that its audience is substantially and not merely incidentally or insignificantly, composed of nonadults ... Whether or not the cigarette industry has deliberately attempted to exploit the large and vulnerable youth market, its advertising, in emphatically reiterating the pleasures and attractions of smoking without disclosing the dangers to health, has exercised an undue influence over the large class of youthful, immature consumers or potential consumers of cigarettes."107(pp110-2) Spurred on by the FTC, the Surgeon General's report, and events like Kent's sponsorship of the debut of the Beatles on US television, many congressmen pressed for legislation on cigarette advertising. ${ }^{108}$ Congressman Morris Udall said: "Who needs enemies when we have friends like the Marlboro Man?".82 (p25)
Congressional initiatives and FTC-proposed regulations were vigorously and effectively resisted by the Tobacco Institute and industry. The tobacco industry committee of lawyers met "almost daily" and "planned the industry argument... and deeply involved itself in the maneuvering in Congress... wrote testimony, drafted bills and amendments, served as central casting for witnesses ... (and) fed friendly congressmen statements and questions." 81 The resistance to a warning requirement frustrated the FTC Chairman, Paul Rand Dixon, who thought the FTC proposals friendly and beneficial to the cigarette industry, saying that "once the courts find that the absence of a warning on the package or in the advertising represents an implied warranty that the product is safe, the industry may indeed appreciate the protection it will have from the kind of rules we have proposed." $" 109$

In the 87th and 88th Congresses, the tobacco lobby successfully defeated 14 House and Senate bills and resolutions seeking warning labels, disclosure of tar and nicotine content or filter effectiveness, or empowering the FTC. ${ }^{110}$ The Cigarette Labelling and Advertising Act that finally passed in 1965 was thought by many to be more of a victory for the cigarette industry than for the health community. ${ }^{111}$ The warning was conditional ("cigarette smoking may be hazardous to your health"), vague (unspecified hazards), and avoided the more specific FTC proposal using the word "death". The industry decided the location and typography of the warning, and the weakened warning was to appear only on packaging, with advertising application explicitly excluded. State and local action that might strengthen the Federal action was preempted. A New York Times editorial called it "a shocking piece of special interest legislation". ${ }^{112,113}$ Congressional action congenial to the cigarette industry's interests was also evident in the rejection of a US Public Health Service request for a modest $\$ 1.9$ million to fund a campaign to teach children about the hazards of cigarette smoking. ${ }^{114}$

Meanwhile smoking among teenagers continued to climb, reaching $53 \%$ of $16-19$ year olds. ${ }^{115}$ In an innovative move, John Banzhaf III filed to the FCC for an application of the Fairness Doctrine to cigarette advertising, arguing that views in opposition to the cigarette industry promotion, such as public service announcements by health organisations, were necessary to protect the public interest. The application was granted in June 1967. ${ }^{116}$ Soon thereafter, public health announcements explicitly about cancer began appearing on the television, after many years of being kept off because they were offensive to the major cigarette sponsors. ${ }^{117}$ Multiple legal petitions were filed to rescind Banzhaf's request on behalf of all three major networks, the $\mathrm{NAB}$, the six major tobacco companies and the Tobacco Institute. ${ }^{118}$ The industry kept the legal pressure up, taking the FCC decision all the way to the Supreme Court. ${ }^{103}$ The mandated presence of anti-smoking messages reduced television's value as a commercial asset, 
and its highly visible and intrusive nature made it increasingly a political liability. ${ }^{119-121}$ The American Cancer Society felt that "the cigarette companies would dearly love to pull out of (television) advertising."117(p185) Doing so would eliminate the provision of free air time to the troublesome anti-smoking spots.

PROMISES TO GET OFF BROADCAST MEDIA

One of the more significant events in the history of US advertising regulation was the removal of cigarette ads from broadcast media, an event judged by Congress to be both dramatic and profoundly significant. The Fairness Doctrine was withstanding the cigarette industry's legal challenges, being upheld by the US Court of Appeals, a ruling which the Supreme Court refused to review on 13 October 1969.122 A bill renewing the 1965 package warning law passed the House of Representatives in June 1969. While that bill was pending, the FTC announced intentions to require that warnings also appear in ads, and the FCC declared rulemaking intentions to ban broadcast advertising. ${ }^{123}$ Both agencies could act, however, only in the event that the advertising provisions of the 1965 law were not extended. The bill passed by the House, however, did extend the preemption of advertising regulation until 1 July 1975, nullifying the FTC and FCC intentions. The House bill went to the Consumer Subcommittee of the Senate Commerce Committee, which held hearings in July 1969, where the ineffectiveness of self-regulation was demonstrated with eloquent simplicity by Michael Pertschuk in a 20 -minute reel of television ads stressing athletes, romance and rock music "all obviously designed to encourage young people to light up and smoke." 124,125

Joseph F Cullman III, the president of Philip Morris and then chairman of the Tobacco Institute, surprised many by announcing that each company would discontinue all broadcast advertising effective September 1970 if granted immunity from anti-trust laws. This was a full three years sooner than a schedule suggested earlier by the NAB. If also released from forward contracts with the networks, they were prepared to discontinue even more promptly. This volunteering left the networks politically isolated in resisting this dramatic change in cigarette advertising practice. The Congressional bill was amended by the Senate several months later (on 12 December 1969) to include a statutory ban on cigarette advertising on broadcast media. The amendment legislatively blocked any backsliding on the promised voluntary cessation and avoided establishing a precedent of exempting the cigarette industry from anti-trust laws. The amended version passed both the House and the Senate in March 1970, becoming law eight months after Cullman's original volunteering. Broadcast advertising for cigarettes ceased after the endof-season football games on 1 January 1971, although "little cigars" continued to be advertised on television for a few years until additional law closed this loophole. For more detail, see the Congressional legislative history. ${ }^{126}$

\section{PERFORMANCE - ACT III}

Despite Cullman's reiteration to Congress of the Cigarette Advertising Code's content, which included a disavowal of promotional association with athletes, within the year professional athletes were under contract to his firm, Philip Morris, to perform in events promoting Virginia Slims. By 1971 eight women professional tennis players were playing a circuit of 20 cities and as many tournament weekends, thereby appearing regularly on television in both live and sports news coverage. ${ }^{127}$ Happily for the cigarette industry, this broadcast coverage did not include any warnings, nor did the FCC ever mandate opposing messages to counterbalance this television exposure. Consumer Reports, which called the volunteering to abandon broadcast media "one of the shrewdest business decisions the cigarette industry ever made", noted the Virginia Slims Tournaments and judged that Cullman's Congressional avowals "sound a bit hollow measured against today's performance". ${ }^{128}$

Now as then, sponsorship of events and teams produces television coverage rich in promotional brand exposure. One tally estimated that the Marlboro Grand Prix coverage, for example, showed the brand name for virtually half of the live coverage time. ${ }^{29}$ Whether live or in news reports, television coverage of many sports events exposes the large-scale signage at many sports stadia, signage strategically placed for natural camera angles. ${ }^{130}$ In none of these cases are there readable warnings or countervailing messages, just the association of cigarettes with sport.

\section{Encore: how sweet it is!}

The problem of candy (sweet) cigarettes seems to have never provoked either explicit promises or performance. In 1967 the FTC complained to the self-regulatory Code Authority about candy and chewing gum being sold in the same or look-alike packages as cigarette brands, judging this "an indirect form of advertising aimed at children ". ${ }^{131}$ Most major brands were involved. At least five US candy firms distributed candy cigarettes imitating existing brands: Camel, Lucky Strikes, L\&M, Marlboro, Pall Mall, Salem, Winston, Chesterfield, Oases (sic), Lark, and Viceroy, with candy versions of L\&M, Camel, Marlboro, Salem, Winston, Lucky Strike, and Pall Mall sold by more than one manufacturer. A chocolate cigarette came from a European source and appeared in packages marked "Made under licence of Philip Morris Inc, New York, NY, USA".

The cigarette sellers disclaimed any intent to lure kids with candy cigarettes, but would not say what action, if any, would be taken against the obvious copyright infringement. When questioned by reporters, the candy makers said 
that "no (cigarette) company had ever suggested that it might take action". Another said: "The companies don't object. That's the point. We've been doing it for many years. They don't care." ${ }^{132}$ Candy cigarettes imitating Camel, L\&M, Lucky Strike, Marlboro, Pall Mall, Salem, Viceroy, and Winston were still available into the $1980 \mathrm{~s},{ }^{133}$ and research has suggested that these candy cigarettes encourage children to smoke. ${ }^{134}$

\section{Conclusions}

Both the Tobacco Institute and the NAB failed in their nominal efforts to restrain the cigarette industry effectively and to protect youth from the inducements of television advertising for cigarettes. Cigarette firms continued to advertise in ways that reached youth with a high frequency despite the threats of impending governmental regulation, despite the exhortations of the trade press such as Advertising Age, despite criticism and cooperation from the NAB, despite the public stances taken by advertising industry leaders, despite the concerns of health professionals, despite the threat of FTC initiatives, despite the Tobacco Institute suggestions, and despite the explicit executive promises in reaction to those suggestions.

These failures of self-regulation were obvious to those closely involved then and are lessons not to be forgotten. The FTC staff reviewed cigarette advertising in 1964, 1967, 1968, and 1969 and judged that all these reviews "amply demonstrate the futility in relying upon voluntary regulation of cigarette advertising to achieve any significant changes in the content and meaning of cigarette advertising". ${ }^{135(\mathrm{p} 27)}$ Senator Robert Kennedy, who had been the US Attorney General, said that "we have witnessed a charade of purported self-regulation for some years. The codes of self-regulation have been largely ineffective, and I see little hope for change". ${ }^{136(\mathrm{p} z)}$

Strongly expressed moral persuasion from multiple sources, both within and without the world of advertising and media management, did little to deter the cigarette industry from pursuing its long-term strategic need-the recruitment of young smokers. The cigarette industry's nominal responses of self-regulatory guidelines proved to be largely ineffective. The US cigarette industry still ignores suggestions for ethical policies, even carefully articulated recommendations that arise from within the advertising trade. ${ }^{137}$

In the midst of the moral debate of the 1960s, Fairfax Cone, a founder of Foote, Cone and Belding, said: "It is either harmful to smoke cigarets (sic) or it is harmless... and advertising should be regulated accordingly and for all media alike." ${ }^{138(\mathrm{p} 132)}$ Advertising Age expressed a very similar view. "Either cigarets (sic) are harmful under conditions which normally apply to their use, and therefore their sale or promotion ought to be restricted in the name of the public good, or they are not. There should not be any pussyfooting involving partial solutions." 139 Reliance on self-regulation is at best a partial solution. Given the attractive and addictive nature of cigarettes and cigarette-related incomes, it may not be a solution at all.

History informs us that, at least for cigarette firms, reliance on self-regulation is inappropriate because it has repeatedly proven to be ineffective. The motivational power of moral restraint seems weak compared to that of mercenary goals and opportunities. The head of the NAB said long ago: "where others have persistently failed to subordinate their profit motives to the higher purposes of the general good health of our young people, then I think the broadcaster should make corrective moves". ${ }^{55(\mathrm{p} 102)}$ Given the failure of cigarette self-regulation, and the inaction of broadcasters in most jurisdictions, it falls to all levels of government in all countries to protect their young people with law and penalties influencing all cigarette marketing mix elements - not just explicit advertising, but also event and sports sponsorships, "brand stretching" efforts, product distribution, packaging, pricing, retail display and sales.

1 Elliott S. Top health official demands abolition of 'Joe Camel' ads. New York Times 1992; March 10: A1,D21 2 Daube $M$. Voluntary agreements: designed to fail. Tobacco Control 1993; 2: 183-4.

3 Warner KE, Butler J, Cummings KM, et al. Report of the Tobacco Policy Research Study Group of Tobaco Marketing and Promotion. Tobacco Control 1992; S19-S22.

4 DiFranza JR, Brown LJ. The Tobacco Institute's 'It's the law' campaign: has it halted illegal sales of tobacco to law' campaign: has it halted illegal sales of tobacco to
children? Am f Public Health 1992; 82(9): 1271-3

5 Jason LA, Ji PY, Anes MD, Birkhead SH. Active ason LA, Ji PY, Anes MD, Birkhead SH. Active
enforcement of cigarette control laws in the prevention of cigarette sales to minors. $\mathcal{F} A M A$ 1991; 266: 3159-61.

6 Coulson WR. Helping youth decide: "when the fox preaches, beware the geese." NY State $\mathcal{F}$ Med 1985 85(7): $357-8$.

7 DiFranza JR, McAfee T. The Tobacco Institute: helping youth say 'yes' to tobacco. F Fam Pract 1992; 34(6): 694-6.

8 Mindell JS. The UK voluntary agreement on tobacco advertising: a comatose policy? Tobacco Control 1993: 2: 209-14.

9 Pollay RW, Lavack A. The targeting of youth by cigarette marketers: archival evidence on trial. In: McAllister L, marketers: archival evidence on trial. In: McAllister L,

10 Tye J. Willy the Penguin and Joe Camel duke it out for the youth market. Tobacco Control 1992; 1: 132-3.

1 Is the youth market fair game? Advertising Age 1983; 54(1/31): M16-7.

12 Pollay RW. Targeting the young is an old story: a history of cigarette advertising to the young. Vancouver BC: UBC Cortory of Advertising Archives, Working Paper 1993. 13 Cigarette industry advertising standards (1291.1). Sesser S. Opium war redux. New Yorker 1993; 69(29): 78-89.

15 Boddewyn JJ. Advertising self-regulation: 16 advanced systems. NY: International Advertising Assoc, 1986.

16 Jones TT, Pickering JF. Self-regulation in advertising : a review. London: Advertising Assoc, 1985.

17 Miracle GE, Nevett TR. Voluntary regulation of advertising: a comparative analysis of the United Kingdom and the United States. Lexington, MA: Lexington Books; 1987.

18 Neelankavil JP, Stridsberg AB. Advertising self-regulation: a global perspective. NY: Hasting House, 1980.

9 Boddewyn JJ. Advertising self-regulation: true purposes and limits. $\mathcal{f}$ Advertising $1989 ; 18(2): 19-27$

20 Levin HJ. The limits of self-regulation. Columbia Law Rev $1967 ; 67: 603-44$.

21 Does cigarette advertising need further self-regulation? Printers' Ink 1952; 241(5): 52,56.

22 Newsreel: scores TV's cigarette ads. Printers' Ink 1954; 246(13): 14

23 AMA explodes at Kent ad. Printers' Ink 1954; 247(1): 13.

24 Giles R. Washington: FTC offers Ink $1954 ; 247(1): 13$. cigarettes. Printers' Ink 1954; 248(13):104.

25 Self regulation - key to better programming and advertising. Printers' Ink 1960; 271(1): 34,38.

26 Lorillard cites role of ads in making it no. 3 cigaret maker Advertising Age 1963; 34(9): 10.

27 Lorillard puts some $\$ 35,000,000$ into ads: cramer. $A d$ vertising Age 1963; 34(15); 2, 56. 
28 Where tobacco companies' ad dollars go. Advertising Age $1964 ; 35(4): 32$.

$\rightarrow$

$=-$

$+$

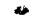

$<$

$-1$

$+\ldots$

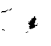

$\div-4$

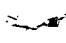

$\therefore$

is

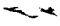

$\cdots$

$\because$

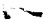

2.
34(7): 8 .

30 Filters, menthols pace cigaret sales increase, says 'Business Week' report. Advertising Age 1963; 34(51): 68

31 Tobacco industry among 'healthiest' in US Economy. US Tobacco f 1963; 180(2): 1, 21.

32 Embattled tobacco's new strategy. Fortune 1963; 67(1): 120.

33 Kent S. How to reach the college market. Printers' Ink $1963 ; 283(7): 24-30$.

34 Selling at "the greatest show on earth." Printers' Ink 1960; 272(8): 52-53.

35 Embattled tobacco's new strategy. Fortune 1963; 67(1): 120

36 Regulate cigaret ads, CU suggests in smoking-health book. Advertising Age 1963; 34(30): 40

37 Beer, cigaret TV ads lure teens via sexual, athletic themes, 'America' writer charges. Advertising Age 1963; 34(1): 12.

38 American, Reynolds, Lorillard aim ads at youth, 'Digest' says. Advertising Age $1963 ; 34(4): 77$.

39 PTA pushes effort against cigaret ad appeal to teens. Advertising Age 1963; 34(23): 78 .

40 ACS anti-smoking push succeeds but resistance looms. Advertising Age 1963; 34(45): 1, 121 .

41 Decency, honesty will help (editorial). Advertising Age

42 Cohen SE. Surgeon General's smoking report to kindle fires of 'What's next?' hassle. Advertising Age 1963; 34(46): 44.

43 RJ Reynolds is leadoff sponsor as '63 baseball emerges from dugout. Advertising Age 1963; 34(11): 10, 112 .

44 Camel to share Huntly-Brinkley news with Texaco. $A d-$ vertising Age 1961; 31(23): 3 .

45 B\&W sponsors 2 bowl games. Advertising Age 1963; 34(43): 72.

46 Three to co-sponsor NBC olympic games; other radio-TV buys. Advertising Age 1963; 34(31): 55 .

47 Pollay RW, Lee JS, Carter-Whitney D. Separate, but not equal: racial segmentation in cigarette advertising. $f$ Advertising 1992; 21(1);45-57.

48 Ford, Marlboro back NFL tilts on CBS-TV; other radioTV buys. Advertising Age 1963; 34(16): 96 .

49 Sponsors back growing list of grid broadcasts. Advertising Age 1963; 34(36): 12 .

50 Pro football may seem tame to giant's Gifford after thrill of making TV ads. Advertising Age 1963; 34(25): 64 .

51 Brickbats deserved, Young says. Advertising Age 1964; 35(5): 3 .

52 Cigarettes: doing fine despite fuss. Printers' Ink 1964; 288(6): 26 .

53 Cigarette ads aim at youngsters still. Printers' Ink 1963; 285(3): 10 .

54 Curbs on cigaret advertising (editorial). Advertising Age $1963 ; 34(1): 16$.

55 Collins hint of 'Corrective action' by radio-TV on cigaret ads stirs hassle. Advertising Age 1962; 33(48): 1, 102.

56 Lucoff $M$. Broadcastings vs. Leroy Collins: a study in media influence. Southern Speech Commun f 1973; 38(4): 309-325.

57 NAB supports Collins; stiffens medical ad code. Advertising Age 1963; 34(4): 1, 85

58 American 'Tobacco sets 'Adult' Theme for Lucky Strikes. Advertising Age 1963; 34(32): 102.

59 American Tobacco using new theme for Lucky Strike. US Tobacco $f$ 1963; 180(7): 14

60 Collins 'resents' Luckies ad; it's 'Brazen and cynical'. Advertising Age 1963; 34(49): 1.

61 What does it mean? Advertising Age 1963; 34(47): 120.

62 This campaign should be dropped (editorial). Advertising Age 1963; 34(50): 20.

63 Plaudits to these 1963 leaders ... boo to these. Printers' Ink $1964 ; 280(1): 42-3$.

64 Cigaret promotions on college campuses to end. Advertising Age $1963 ;$ 34(26): 1, 108

65 RJ Reynolds drops radio use in teen-oriented hours. Advertising Age 1964; 35(6): 6, 93.

66 Tobacco industry to weigh ad code on youth appeals at July 9 meeting. Advertising Age 1963; 34(27): 3 .

67 Don't restrict hours; avoid shows with kid appeal, tobacco men urged. Advertising Age 1963; 34(29): 1, 8.

68 Pollay RW. The major minor issue: children, cigarettes and advertising self-regulation in the sixties. Proc Am Acad Advertising 1993: 2-11.

69 Cigarette controls: a sick joke so far. Consumer Reports $1967 ; 33(2): 98$

70 Decency, honest will help. Advertising Age 1963; 34(47): 22.

$71 \mathrm{DDB}$ won't handle cigaret client, Bernbach says. $A d-$ vertising Age 1964; 35(6): 91 .

72 Agency would refuse cigaret client: Ogilvy. Advertising Age $1964 ; 35(6): 91$.

73 O'Gara JV, Foote Resigns at McCann; 'Won't Promote Cigarets.' Advertising Age 1964; 35(38): 1, 8 .

74 Brickbats deserved, Young says. Advertising Age 1964 35(5): 3 .

75 Make cigarets unfashionable via ads, Jones urges. $A d$ vertising Age 1964; 35(19): 1, 107.

76 Daniels D. Giants, pigmies(sic) and other advertising people. Chicago: Crain, 1974 .

77 Some admen tell need for 'caution' in evaluating potential cigaret account. Advertising Age 1964; 35(7): 3 .
78 Whelan EM. A smoking gun: how the tobacco industry gets away with murder. Philadelphia: Geo Stickley, 1984.

79 Whiteside T. Annals of advertising: cutting down. New Yorker $1970 ; 46(44)$ : 42-95.

80 Bar cigaret appeals to youth, code unit urges. Advertising Age $1964 ; 35(4): 1,82$.

81 Drew EB. The quiet victory of the cigarette lobby: how it found the best filter yet-Congress. Atlantic Monthly $1965 ; 216(3): 76-80$

82 Cigarette Labelling and Advertising 1965. Hearing before the Committee on Interstate and Foreign Commerce, House of Representatives, 89th Congress, Ser. No. 89-11. 83 Cohen S. Tobacco code seen breaking new legal ground on industry self rule. Advertising Age 1964; 35(26): 28

84 Cigaret code gets conditional anti-trust okay. Advertising Age 1964; 35(25): 1

85 Cullman lauds code. Advertising Age 1966; 37(18): 107.

86 Some fighters and some switchers. Printers' Ink 1964; 289(6): 7 .

87 PI editors give the marketing slant: cigarettes. Printers' Ink $1965 ; 289(12): 53$

88 How cigarette code affects advertisers. Printers' Ink 1965; 291(11): 31-34

89 Christopher $M$. Code board authorizes cigaret ad guidelines. Advertising Age 1966; 37(41): 1, 127.

90 Code authority clarifies rules for cigaret ads. Advertising Age $1967 ; 38(30): 3$

91 Yeaman hails erasing of code rules on cigarets. Advertising Age 1967; 38(17): 1, 123.

92 Christopher $M$. Code revamp aims to obviate cigaret ad ban. Advertising Age 1969; 40(13): 1, 30.

93 Withdrawal by American perils tobacco code. Advertising Age 1967; 38(36): 1, 55 .

$94 \mathrm{Christopher} M$. Six cigaret marketers rally round ad code. Advertising Age 1967; 38(37): 1, 113.

95 Blum S. An ode to the cigarette code. Harpers Magazine $1966 ; 232(1390): 60-3$

96 Baker SS. The permissable lie: the inside truth about advertising. NY: World Publishing, 1968.

97 Sullivan, Stauffer, Colwell \& Bayles Marketing Research Dept. National smoking habits study : findings significant to Pall Mall famous cigarettes. August 1964 .

98 Code bars ads for cigarets on youth-appeal TV. Advertising Age 1966; 37(19): 1, 181.

99 Interpretation of cigaret code gives 'Hillbillies' a pass. Advertising Age 1967; 38(8): 1A

100 RJ Reynolds to drop' 'Hillbillies' under cigaret code, Advertising Age 1967; 38(20): 2

101 NAB cigaret code met plenty of resistance, testimony reveals. Advertising Age 1969; 40(24): 95.

102 Federal Trade Commission. Report to Congress: Pursuant to the Federal Cigarette Labelling and Advertising Act. Washington, DC: FTC, 1969

103 Doron G. The smoking paradox: public regulation in the cigarette industry. Cambridge: Abt Books, 1979.

104 Code authority minutes show trials, tribulations of in dustry self regulation. Advertising Age 1969; 40(25): 106

105 Unpublished study finds health-sell contradiction in ads may be insoluble. Advertising Age 1969; 40(23): 1, 119

$106 \mathrm{Bell} \mathrm{H}$. Broadcast cigarette advertising report (confidentia memo). National Association of Broadcasters Code authority memorandum, $1966 ; 9 / 26$.

107 A report on cigarette advertising and output. Washington DC: FTC, 1964

108 Cigarette ads still run on kids' TV, Magnuson warns. Advertising Age 1965; 36(39): 1, 123.

109 Fighting warning labels is losing game, FTC tells tobacco men, admen. Advertising Age 1964; 35(12): 1, 114.

110 Wegman RA. Cigarettes and health: a legal analysis. Cornell Law $Q 1966 ; 51(4): 678-759$.

111 Cohen SE. This week in Washington: cigaret labelling friends, foes claim victory; how will law be enforced. Advertising Age 1965; 36(28): 70 .

112 Cigarettes vs. FTC. (editorial), $N Y$ Times 1965; July 9 : 28 .

113 Proposal minimal: 'NY Times'. Advertising Age 1964, $35(26): 82$.

114 House unit rejects US plan to teach kids about cigarets. Advertising Age 1964; 35(39): 98

115 Teen smoking grows despite curb on ad appeals, poll finds. Advertising Age 1966; 37(44): 58

$116 \mathrm{FCC}$ applies fairness rule to cigaret ads. Advertising $\mathrm{Age}$ $1967 ; 38(23): 1$.

117 Glatzer R. The last cigarette campaign. In: Glatzer R. The new advertising: the great campaigns from Avis to new advertising: the great campaigns from A

118 Whiteside T. Selling death : cigarette advertising and public health. NY: Liverright, 1975 .

119 Miles RH. Coffin nails and corporate strategies. Englewood Cliffs: Prentice-Hall, 1982

120 Sobel R. They satisfy: the cigarette in american life. Garden City, NJ: Anchor Press, 1978

121 Warner KE. Clearing the airwaves: the cigarette ad ban revisited. Policy Analysis 1979; 5: 435-450.

122 Banzhaf v. FCC, 405 F.2d 1082, 1968

123 FCC Docket No. 1834; 34 FR 1959, Feb 11, 1969.

124 Showdown in Marlboro Country. Consumer Reports 1969 ; 34(9): 516-521.

125 Pertschuk M. Giant killers. NY: Norton, 1986

126 US code congressional and administrative news 1970; PL 91-222: 2652-2680.

127 Philip Morris. Virginia Slims Circuit (Media Guide). NY Philip Morris, 1976: 1-128. 
128 New medium for the message. Consumer Reports 1976; 41(5): 277-279.

129 Blum A. The Marlboro grand prix: circumvention of the television ban on tobacco advertising. $N$ Engl $f \mathrm{Med}$ 1991; 324: $913-7$.

130 Ross, E. Cigarette ads not good sports. Christian Sci Monitor 1990; May 25-31:6.

131 Ban candy 'Cigarets' FTC asks tobacco code. Advertising Age 1967; 38(8): 191.

132 Tobacco marketers disclaim intent to lure kids with candy cigarets. Advertising Age 1967; 38(11): 3, 97. 133 Blum A. Candy cigarettes. $N$ Engl F Med 1980; 302(17):
134 Klein, JD, Forehand B, Oliver J, Petterson CI, Kupersmidt JB, Strecher V. Candy cigarettes: do they encourage children's

135 Report to children's smoking? Pediatrics $1992 ; 89: 1-5$. Labelling and Advertising Act. Washington, DC: FTC 969.

136 Proc First World Conference on Smoking and Health. New York: American Cancer Society, 1967

137 Koeppel D. An ethical plan for tobacco marketers. Adweek's Marketing Week 1990; May 28: 18-22.

138 Cone FM. The Blue Streak: some observations mostly about advertising. Chicago: Crain Communications, 1973.

139 Decency, honesty will help. Advertising Age 1963; 34(47):

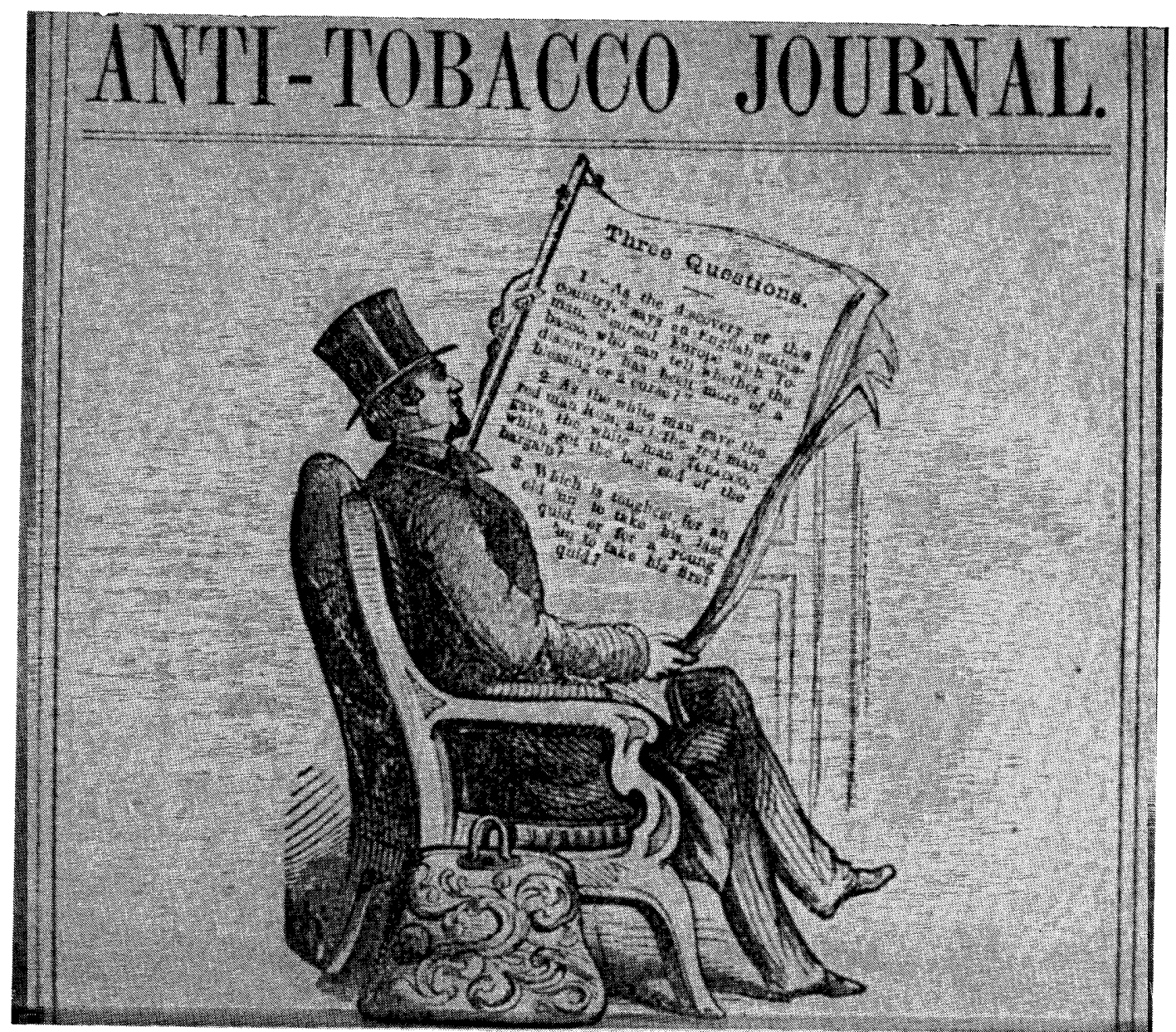
$\forall x$
\%
-

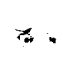
35
$7 \div$
3
$\therefore$
$+\div$

$=-$

$+$

$x:$

Anti-Tobacco Journal, volume 1, issue 5, fuly/August 1860. Source: fohn Slade. 